\title{
報交
}

\section{化學變化の熱力學的研究（第三報） 水酸化カドミウムの熱力學的研究}

\author{
（昭和二年三月十八日受领＼cjkstart昭和二年六月二十五日印刷）
}

石川總雄柴田榮一

\section{[1.] 水酸化カドミウムの Activity 皘 $\left[\mathrm{Cd}^{++}\right]\left[\mathrm{OH}^{-}\right]^{2}$}

水酸化カドミウムの溶解度に就ては W. Herz ${ }^{1)}$ 及 Bodländer ${ }^{22}$ の时究あり著者等は更に次の三種 の力法によりて其の Activity 積を決定せり。第一は Cd amalgam / Cd(OH) $)_{2} \mathrm{~N} \mathrm{NaOH} \cdot \mathrm{HgO} \mid \mathrm{Hg} な$ 万可逆電池の電動力の测定に基き第二は Cdamalgam | $\mathrm{CdSO}_{4}$ 溶液 | 飽和 $\mathrm{KCl}$ 溶液 | N/ $10 \mathrm{KClHgCl}$ I $\mathrm{Hg}$ なる組合せの電池を作り $\mathrm{CdSO}_{4}$ 溶液中に次第に N/10 NaOH を滴下し $\mathrm{Cd}^{++}$を沈澱せしめつ つ其の電動力を测定する方法にして第三は 水酸化カドミウム能和溶液の電氣傳導度の湘定による ものなり、之等の結果及 Herz, Bodländer 等の結果ミの比較に就ては實驗記载の後に讓る。

\section{實驗}

\section{第一、Cd amalgam | $\mathrm{Cd}(\mathrm{OH})_{2} \mathrm{NNaOH} \mathrm{HgO} \mid \mathrm{Hg}$ の電動力測定}

（1）材料 ${ }^{3)} \mathrm{Cd}$ amalgam 常法により電解的に $10 \%$ amalgam 乍製して用ひたり。 水酸化カドミウム 沈澱法により直ちに純粹なる水酸化物を 得るは困難なるを以て $\mathrm{CdSO}_{4}$ 溶液に $\left(\mathrm{NH}_{4}\right)_{2} \mathrm{CO}_{3}$ 在加へ監基性 監を沈澱せしめ之を乾燥し電氣爐中にて $400^{\circ} \mathrm{C}$ 以上に熱し純粋 なる褐色の酸化カドミウム在得たり、㿼基性炭酸カドミウムの 組成は勿論一定ならざるべきも熱天科虎以て预め其の完全分解

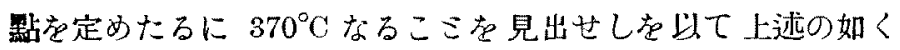
$400^{\circ} \mathrm{C}$ なる温度を用ひたり。

$\mathrm{NaOH}$ 水溶液 金屬ナトリウムを用ひ炭酸監在含まざる $1 \mathrm{~N}$ 溶济を作れり。

酸化水銀 硝酸第一水銀の熱分解によれり

(2) 電池の㯨成及测定結果

用ひたる電池は第 1 圖の如き形を有し其の數個を同時に作り て恒温槽 $\left(25^{\circ} \pm 0.02^{\circ} \mathrm{C}\right)$ 中に置き其の電動力在測定せり。電動 力測定法は第一報の記載に同じ。

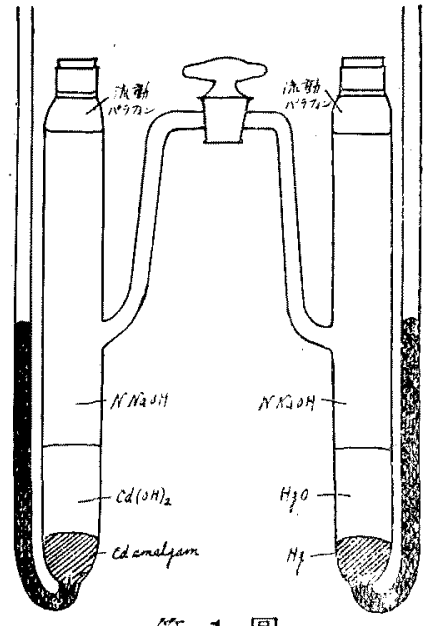

第 1 圖

1) Z. anorg. allgem. Chem., 24, 123 (1900).

2) Z. physik. Chem., 27, 66 (1898).

3）材料は總て Kahlbaum 製なり。

4) J. Chem. Soc., 99, 845 (1911). 


$$
\text { 第 } 1 \text { 表 }
$$

Cd amalgam $\left|\mathrm{Cd}(\mathrm{OH})_{2} \mathrm{NNaOH} \mathrm{HgO}\right| \mathrm{Hg}$

$25^{\circ} \mathrm{C}$ に於辇る電動力

\begin{tabular}{|c|c|c|c|c|}
\hline 縞 過 & $\begin{array}{l}\text { 電 池 番 號 } \\
\text { 數 }\end{array}$ & No. 1 & No. 2 & No. 3 \\
\hline & 5 & 0.8190 & $0.82+2$ & 0.8242 \\
\hline & 10 & 0.8345 & 0.8337 & 0.8433 \\
\hline & 15 & 0.8457 & $0.8+35$ & 0.8523 \\
\hline & 20 & $0.85: 4$ & 0.8513 & 0.8568 \\
\hline & 25 & 0.8560 & 0.8542 & 0.8566 \\
\hline & 30 & 0.8585 & 0.8560 & 0.8572 \\
\hline & 35 & 0.8599 & 0.8580 & 0.8582 \\
\hline & 40 & 0.8604 & 0.8590 & 0.8572 \\
\hline & 45 & 0.8610 & 0.8599 & 0.8580 \\
\hline & 50 & 0.8615 & 0.8581 & 0.8593 \\
\hline & 55 & 0.8599 & 0.8588 & 0.8590 \\
\hline & 60 & 0.8603 & 0.8596 & 0.8594 \\
\hline 本 & 均 值 & $\begin{array}{c}0.8605 \\
(35 \text { 日以後) }\end{array}$ & $\begin{array}{c}0.8596 \\
\text { (35 日以後) }\end{array}$ & $\begin{array}{c}0.8592 \\
(50 \text { 日以後) }\end{array}$ \\
\hline
\end{tabular}

$$
\mathrm{E}_{998}=0.8598
$$

第1表に於ける测定結果を見万に之等の電池が一定の電動力を呈するに煩る長時間か要す、之れ 用ひたる酸化カドミウムがアルカリによる水酸化カドミウムへの變化が極めて痋々たるによる尚此 變化ミアルカリの濃度ミの關係に就ては後節に於て述ぶべし。

（3）水酸化カドミウムのActivity 積の計算

第 1 表の實驗結果ミして

$\mathrm{Cd}$ amalgam $\left|\mathrm{Cd}(\mathrm{OH})_{2} \mathrm{~N} \mathrm{NaOH} \mathrm{HgO}\right| \mathrm{Hg} \cdots \cdots \cdots \cdots \cdots \cdots . . . \mathrm{E}_{298}=0.8598$

更に $\mathrm{Cd}$ 及 $\mathrm{Cd}$ amalgam 間及 $\mathrm{Hg} \mid \mathrm{HgO}, \mathrm{N} \mathrm{NaOH}$ の電動力ミして

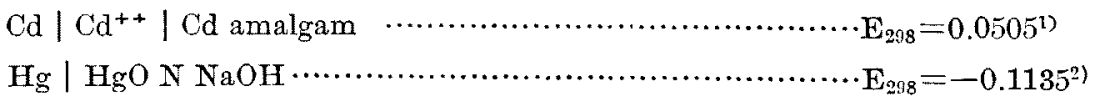

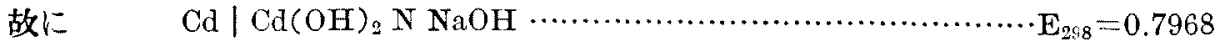

なる峞以て $1 \mathrm{~N} \mathrm{NaOH}$ 中に於ける $\mathrm{Cd}(\mathrm{OH})_{2} よ り$ 生する $\mathrm{Cd}^{++}$の Activity は、 $\mathrm{E}=\mathrm{E}^{\circ}-\frac{\mathrm{RT}}{\mathrm{nF}} \ln \left[\mathrm{Cd}^{++}\right]$ に於て $\mathrm{E}=0.7968, \mathrm{E}^{\circ}=0.3947$ な入れて $\left[\mathrm{Cd}^{++}\right]=2.54 \times 10^{-14}$ こなる、此處に $\mathrm{E}^{\circ}$ は Horsch ${ }^{3)}$ の與 へたる Cd amalgam $\left|\mathrm{Cd}^{++} \mathrm{E}^{\circ}=0.3442 こ \mathrm{Cd}\right| \mathrm{Cd}^{++} \mid \mathrm{Cd}$ amalgamに對する最も正確なる值こ思は るる Hulettの值 0.0505 こを加へて得たるなり。今 $1 \mathrm{~N} \mathrm{NaOH} の$ Activity coefficient $0.68^{4)}$ 用ひ $\mathrm{Cd}(\mathrm{OH})_{2}$ の Activity 積を䀠出すれば $\left[\mathrm{Cd}^{++}\right]\left[\mathrm{OH}^{-}\right]^{2}=2.54 \times 10^{-14} \times 0.68^{2}=1.17 \times 10^{-14}$ こなる。

1) Trans. Am. Electrochem. Soc., 7, 333 (1905).

2) J.Chem. Soc., 99, 845 (1911).

3) J. Am. Chem. Soc., 41, 1787 (1919).

4) J. Am. Chem. Soc., 47, 680 (1925). 


\section{第二、電壓滴定法}

$\mathrm{Cd}$ amalgam | $0.04 \mathrm{~N} \mathrm{CaSO}_{4}$ (100 c.c.) | 飽和 $\mathrm{KCl}$ 溶液 $|0.1 \mathrm{~N} \mathrm{KCl} \mathrm{HgCl}| \mathrm{Hg}$ なる電池を

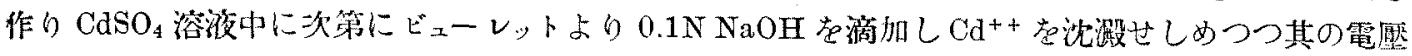

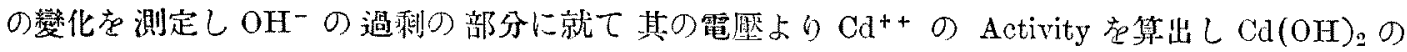
Activity 積苼求さる方法にして其の装置は第 2 圖に示せる如し。此滴定の際最も注意すべきここは 生じたる $\mathrm{Cd}(\mathrm{OH})_{2}$ の沈淑をして Cd amalgam の表面に沈積せしめざるここなり、然らざれ恰電壓 は次第に降下し一定こなり難し故に溶液を 極めて迅速に嫴汼せしめたり。第 2 圖に於 $\tau A$ は $0.04 \mathrm{~N} \mathrm{CdSO}_{4}$ 溶液 100 c.c. 施入る 万內容 300 c.c.の器なり。 B は內徑 $1 \mathrm{~cm}$ の皿の底に白金を封じたる電栖にして皿の

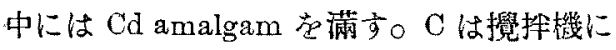
してDは監化加里の飽和溶液を有し Eは甘 承電極なり。全體它 $25^{\circ} \pm 0.02^{\circ} \mathrm{C}$ の恒溫槽 にWの染さまで沈ましす5。加へたる苛性曹 達溶液のc.c. 數ミ䉓壓ミの關係は次の如し。

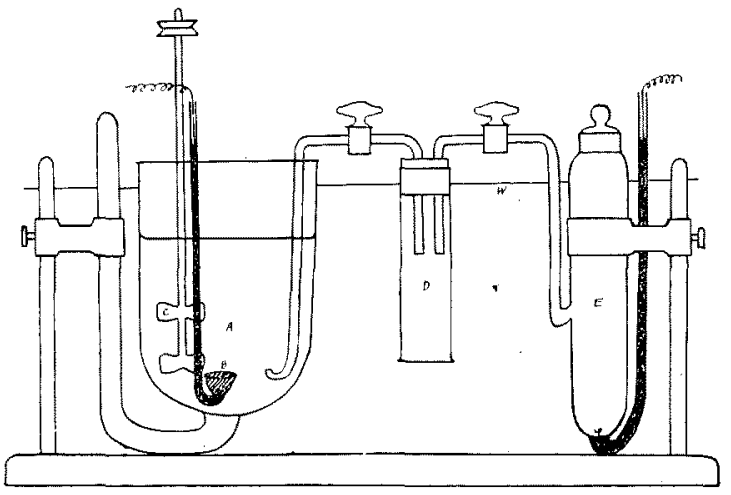

第 2 圖

第 2 表

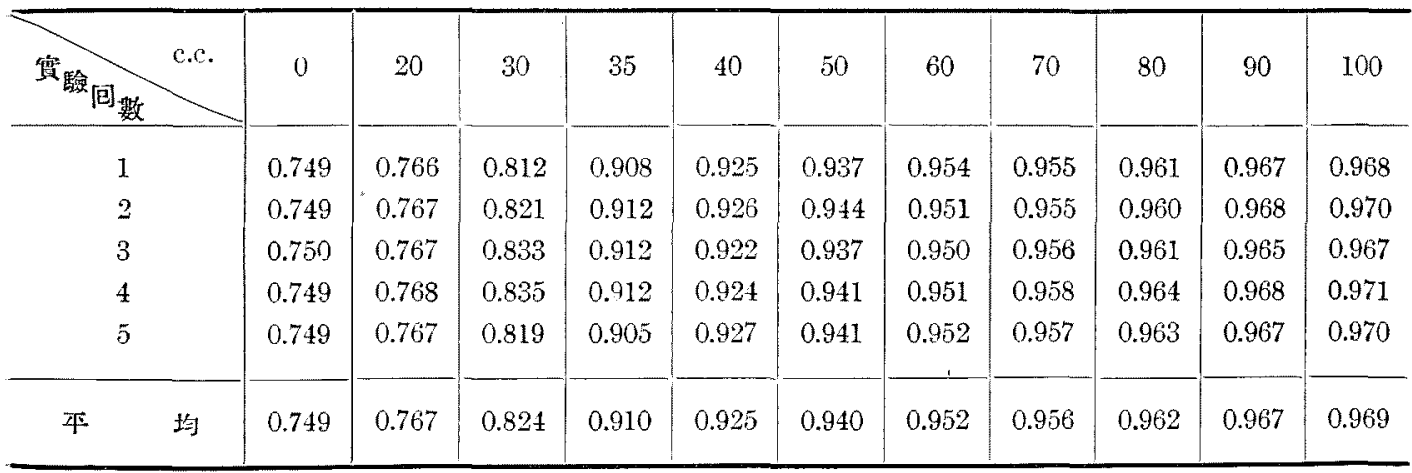

此の關係を曲線を以て示せば次頁第 3 圖の如し。

此の圖に就て見るに溶液中の $\mathrm{Cd}^{++}$の減少するに從つて次第に電歷は上る而して $\mathrm{Cd}^{++}$を完全に 沈澱せしもる第には理論上 40 c.c.の $0.1 \mathrm{~N} \mathrm{NaOH}$ を要するなり。然るに電歷の急激なる上显は恰

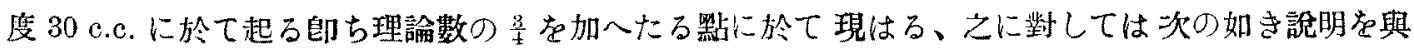
八得へし。アルカリを少し宛加へて生する沈澱は監基性監なるここは疑なかるべく理論數の量な加

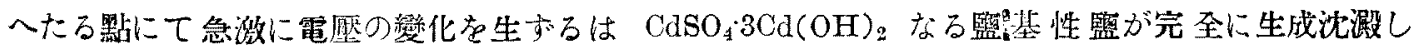
$\mathrm{Cd}^{++}$の急激なる減少を生するによるものならん、其の後更にアルカリを加ふるに從ひ電㻺の次第 に上昇するは此監基性監が $\mathrm{Cd}(\mathrm{OH})_{2}$ に變じ二者の溶解度の美異に基く $\mathrm{Cd}^{++}$の減少によるものな

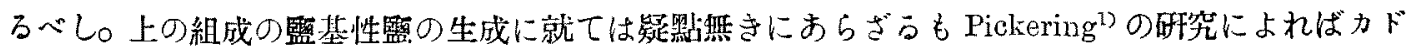

1) J. Chem. Soc., 91, 1986 (1907). 
ミウム監溶液にアルカリを少し宛加へたる場合に生 ボここが芣告せられあり。

第3 表に於て第一行は加へられたる $\frac{\mathrm{N}}{10} \mathrm{NaOH} の$ c.c. 數、第二行は 全電池の電動力、第三行は全電池 の電動力に $\mathrm{Cd}-\mathrm{Cd}$ amalgam 閒の艘位差 0.0505 を 加へそれより $0.1 \mathrm{~N}$ 甘氷電極の電位差 $0.335^{1)}$ を減じ たる $\mathrm{Cd} \mid \mathrm{Cd}(\mathrm{OH})_{2} \mathrm{x} \mathrm{OH}^{-}$の電位差 (E) を示す。此 の値より $\mathbf{E}=\mathbf{E}_{0}-\frac{\mathrm{RT}}{2 \mathrm{~F}} \ln \left[\mathrm{Cd}^{++}\right] に よ り\left[\mathrm{Cd}^{++}\right]$を 出せり。第四行は $\left[\mathrm{Cd}^{++}\right]$定す。第五行の $\left[\mathrm{OH}^{-}\right]$は 過剩の泀性曹達の量こ浴液の全容積この比より濃度 を算出し之れに苛性曹達の各漫度に對する activity coefficient") を乘じて出せるものなり。第六行は水酸 化カドミウムの Activity 積を示す。即ち最後の結果 こして $\left[\mathrm{Cd}^{++}\right]\left[\mathrm{OH}^{-}\right]^{2}=1.0 \times 10^{-13}$ te得。

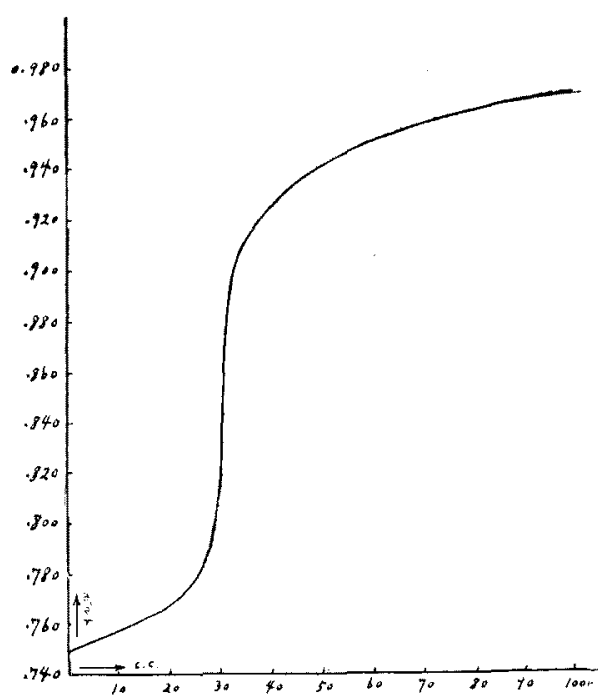

第 3 德 第 3 表

\begin{tabular}{|c|c|c|c|c|c|}
\hline $\mathrm{NaOH}$ c.c. & 測定优(ボルト & 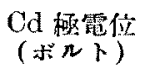 & {$\left[\mathrm{Cd}^{++}\right]$} & {$\left[\mathrm{OH}^{-}\right]$} & {$\left[\mathrm{Cd}^{++}\right]\left[\mathrm{OH}^{-}\right]^{2}$} \\
\hline 30 & 0.824 & 0.540 & $1.2 \times 10^{-6}$ & - & - \\
\hline 35 & 0.910 & 0.626 & $1.5 \times 10^{-8}$ & - & - \\
\hline 40 & 0.925 & 0.641 & $4.8 \times 10^{-9}$ & - & - \\
\hline 50 & 0.940 & 0.656 & $1.4 \times 10^{-9}$ & $6.75 \times 10^{-3}$ & $0.6 \times 10^{-13}$ \\
\hline 60 & 0.952 & 0.668 & $7.4 \times 10^{-10}$ & $1.12 \times 10^{-2}$ & $0.9 \times 10^{-13}$ \\
\hline 70 & 0.956 & 0.672 & $4.3 \times 10^{-10}$ & $1.56 \times 10^{-2}$ & $1.0 \times 10^{-13}$ \\
\hline 80 & 0.962 & 0.678 & $2.7 \times 10^{-10}$ & $1.96 \times 10^{-2}$ & $1.0 \times 10^{-13}$ \\
\hline 90 & 0.967 & 0.683 & $1.8 \times 10^{-10}$ & $2.3 \times 10^{-2}$ & $1.0 \times 10^{-13}$ \\
\hline 100 & 0.969 & 0.685 & $1.6 \times 10^{-10}$ & $2.6 \times 10^{-2}$ & $1.0 \times 10^{-13}$ \\
\hline
\end{tabular}

\section{第三、軋氮傳遒度の測定}

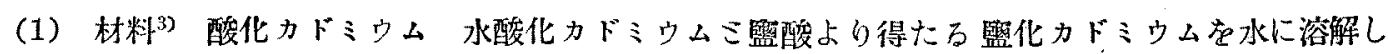

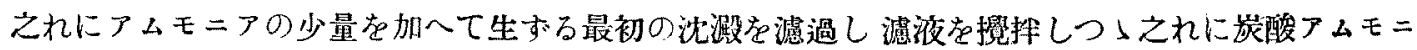
アの溶液を加へて全部の $\mathrm{Cd}^{++}$を沈澱せしむ沈澱は多量の水を以てよく傾滨洗涤し沈降し難くなる

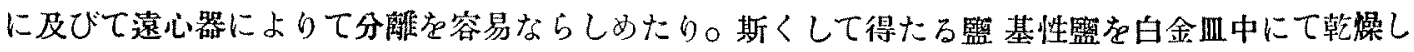

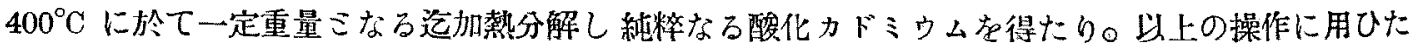
る水は傅導度测定用の水にして其の比傳導度は $1.35 \times 10^{-6}$ なり。

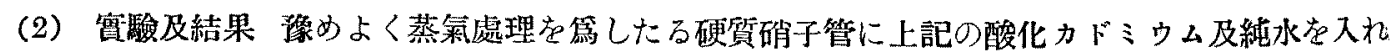
上部の空氣を異空ボンプにて除去したる後融封す、同時に純水のみを入れたるものを同榬に作り之

1) Lewis Randall: Thermodynamics p. 406.

2) Harned: J. Am. Chem. Soc., 47, 680 (1925).

3) 材料は總て Kahlbaum 製なり。 
等の多数を $25^{\circ} \pm 0.02^{\circ} \mathrm{C}$ の恒溫槽中にて振蕰して 飽和せしも。適當なる時期に浴液及純水の管をこ

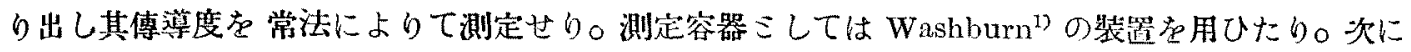
揭ぐる溶液の傅導度は窗测のものより 水の其れを引去りたるものなり、之れを第二行に示す、第三 。行は之れより算出せる $\mathrm{Cd}(\mathrm{OH})_{2}$ の濃度(モル/立)客示し第四行は Activity 積走示方。

\begin{tabular}{|c|c|c|c|}
\hline 䌌過日數 & 溶液比傳導度一水此傳導度 & {$\left[\mathrm{Cd}(\mathrm{OH})_{2}\right]$} & {$\left[\mathrm{Cd}^{++}\right]\left[\mathrm{OH}^{-}\right]^{2}$} \\
\hline 12 & $1.24 \times 10^{-4}$ & $2.81 \times 10^{-4}$ & $8.8 \times 10^{-11}$ \\
\hline 15 & $1.18 \times 10^{-4}$ & $2.68 \times 10^{-4}$ & $7.7 \times 10^{-11}$ \\
\hline 22 & $1.23 \times 10^{-4}$ & $2.79 \times 10^{-4}$ & $8.7 \times 10^{-11}$ \\
\hline 28 & $1.24 \times 10^{-4}$ & $2.80 \times 10^{-4}$ & $8.8 \times 10^{-11}$ \\
\hline 平均值 & $1.22 \times 10^{-4}$ & $2.77 \times 10^{-4}$ & $8.5 \times 10^{-11}$ \\
\hline
\end{tabular}

\section{結果に就ての批判}

上上得たる $\mathrm{Cd}(\mathrm{OH})_{2} の$ Activity 積を比較すれば次の如し。

方 法

(1) 可逆電池電動力测定

$\left[\mathrm{Cd}^{++}\right]\left[\mathrm{OH}^{-}\right]^{2}$

(2) 電筀滴定法

$1.17 \times 10^{-14}$

(3) 傅導度测定

$1.0 \times 10^{-13}$

$8.5 \times 10^{-11}$

之等の力法中最も完至こ見るべきものは第一の可逆電池の電動力測定によるものにして第二の電 壁滴定法に於ては前にも述へたる如く電塺は常に造少ならんこする傾向を有し正しく本衡の狀態の

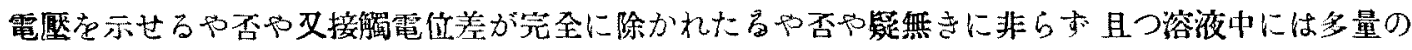

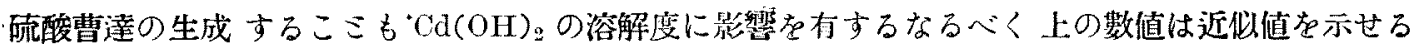
ものミ見ろべきなり、第三の傳導度测定によるものは其の值更に大なりてれ極めて注意して富驗せ しに拘ら桒恐らく微量の電解翼の夾雜によるものなるへし。今之等の檤より $\mathrm{Cd}(\mathrm{OH})_{2}$ の溶解度を 算出し Herz 及 Bodländer の決定せる溶解度ミ比較すれば゙次の如し。

$$
\mathrm{Cd}(\mathrm{OH})_{2} \text { の)溶解度 }
$$
(1) の方法
$1.4 \times 10^{-5}$ モル/立
(2) の方法
$2.9 \times 10^{-5} \quad$,
(3) の方法
$2.8 \times 10^{-4}$,
Herz
$2.6 \times 10^{-4}$,
Bodländer ${ }^{2}$
$1.8 \times 10^{-5}$,

Herz の値は著者筹の傳導度测定より 得たる値こ圣く一致せるものなるが此の值は $\mathrm{Cd}\left(\mathrm{NO}_{3}\right)_{2}+$ $2 \mathrm{NH}_{4} \mathrm{OH} \rightleftharpoons \mathrm{Cd}(\mathrm{OH})_{2}+2 \mathrm{NH}_{4} \mathrm{NO}_{3}$ なる本衡の测定より決定せられたもるのなるも錯イオンの生

1) Catalog. No. 48 p. 18 Leeds \& Northrup Company.

2) Herz の論文及び Gmelin 0 Handbuch K Bodländer の值として $3.5 \times 10^{-5}$ 古記截しあれど原論文より 时かなる如く之れ equivalent/L 單位なることに注堭すいきす。 


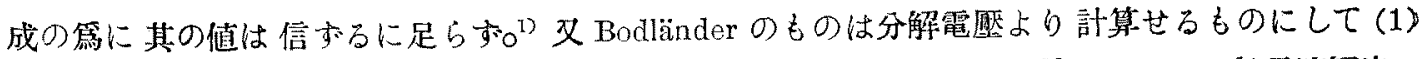
の方法ミよく一致す。即ち $\mathrm{Cd}(\mathrm{OH})_{2}$ O Activity 積ミしては $\left[\mathrm{Cd}^{++}\right]\left[\mathrm{OH}^{-}\right]^{2}=1.17 \times 10^{-14}$ 及溶解度ミ

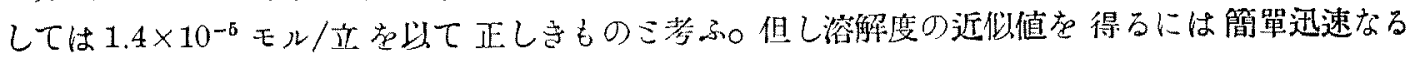
(2)の電原滴定法にて充分なるべし。

此の Activity 積を他の既に知られたる二偪金屬の水酸化物のものミ比較すれば其の大さ略一致す 万を見る。

$\begin{array}{ll}\mathrm{Cd}(\mathrm{OH})_{2} & 1.17 \times 10^{-14} \\ \mathrm{Zn}(\mathrm{OH})_{2} & 1.8 \times 10^{-14} \\ \mathrm{Mn}(\mathrm{OH})_{2} & 4.0 \times 10^{-14} \\ \mathrm{Fe}(\mathrm{CH})_{2} & 1.6 \times 10^{-14}\end{array}$

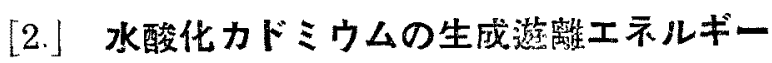

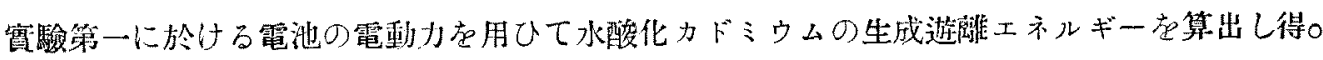

$\mathrm{Cd}($ amalgam $)+\mathrm{HgO}+\mathrm{H}_{2} \mathrm{O}\left(\mathrm{N} \mathrm{NaOH}\right.$ 中の) $=\mathrm{Cd}(\mathrm{OH})_{2}+\mathrm{Hg}_{g} ; \Delta \mathrm{F}_{\mathrm{rr} 8}=-39678$ cal. $\cdots \cdots(1)$

$$
\mathrm{Cd}=\mathrm{Cd} \text { (amalgam); } \Delta \mathrm{F}_{\mathrm{gng}}=-2331 \text { cal. } \cdots \cdots(2)
$$

又苛性曹達水浴液の蒸氣厴に關する Dieterici 及 Tammann の各々 $0^{\circ} \mathrm{C}$ 及び $100^{\circ} \mathrm{C} に$ 於ける测定値

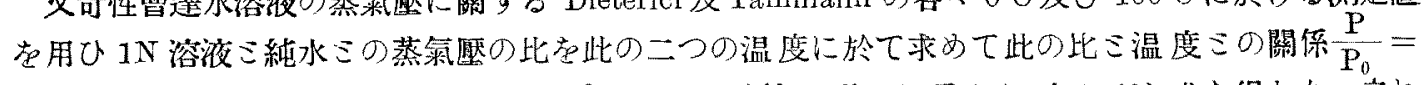
0.972-0.00003t 出し此の比の值存 $25^{\circ} \mathrm{C}$ に於て計算し其の結果より次の（3）式在得たり。之れ Brönsted ${ }^{2)}$ 做ひたる方法なり。

$$
\mathrm{H}_{2} \mathrm{O}=\mathrm{H}_{2} \mathrm{O}\left(\mathrm{N} \mathrm{NaOH} \text { 中の); } \Delta \mathrm{F}_{298}=-17 \mathrm{cal}\right. \text {. }
$$

(1)，(2)及ひ (3) 式在加人て次式在得。

$$
\begin{aligned}
& \mathrm{Cd}+\mathrm{HgO}+\mathrm{H}_{2} \mathrm{O}=\mathrm{Cd}(\mathrm{OH})_{2}+\mathrm{Hg} ; \Delta \mathrm{F}_{298}=-42026 \mathrm{cal} \text {. } \\
& \mathrm{Hg}+\frac{1}{2} \mathrm{O}_{2}=\mathrm{HgO} \\
& \text {; } \Delta \mathrm{F}_{2,18}=-13808 \mathrm{cal}^{3} \\
& \mathrm{H}_{2}+\frac{1}{2} \mathrm{O}_{2}=\mathrm{H}_{2} \mathrm{O} \\
& \text {; } \Delta \mathrm{F}_{29 \mathrm{~s}}=-56560 \mathrm{cal}^{\mathrm{t}}{ }^{\mathrm{f}}
\end{aligned}
$$

然るに

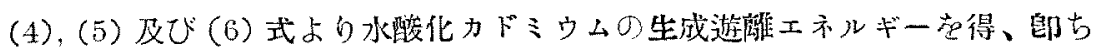

$$
\mathrm{Cd}(\mathrm{s})+\mathrm{H}_{2}(1 \mathrm{Atm} .)+\mathrm{O}_{2}(1 \mathrm{Atm} .)=\mathrm{Cd}(\mathrm{OH})_{\mathrm{S}}(\mathrm{s}) ; \Delta \mathrm{F}_{\mathrm{s} \Omega 8}=-112394 \mathrm{cal} \text {. }
$$

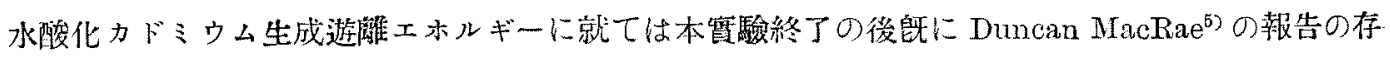
するここを注意せられたり。同氏は本能驗第一に於けるこ全く同一の電池に就て测定を行ししが其 の队唯一個のみ一定檤在示し其電動力 $\mathrm{E}_{998}=0.8595$ にして本賽駸に於ける本均值 0.8598 にく一致

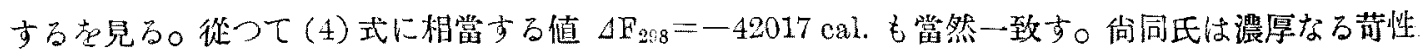

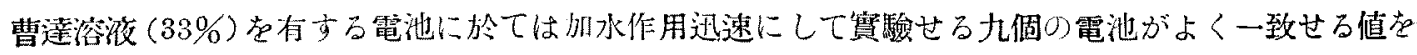

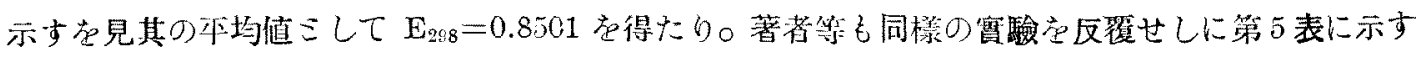
如くよく一致する値在得、同氏の結果の正しきここ虎知れり。

1) Gmelin: Handbuch der anorg. Chem., Cadmium y. 73.

2) Zeit. physik. Chem. 65, 841909.

3) Lewis Randall: Thermodynamics p. 48 !.

4) ibid., p. 485 .

5) Dissertation Massachusetts institute of technolog, $191 \%$. 
第 5 表

$\mathrm{Cd}$ amalgam $\left|\mathrm{Cd}(\mathrm{OH})_{2} 33 \% \mathrm{NaOH} \mathrm{HoO}\right| \mathrm{Hg}$ の電動力 $\left(25^{\circ} \mathrm{C}\right)$

\begin{tabular}{|c|c|c|c|c|c|c|}
\hline 經過日數 & No. 1 & No. 2 & No. 3 & No. 4 & No. 5 & No. 6 \\
\hline 5 & 0.85017 & 0.85011 & 0.85007 & 0.85003 & 0.85035 & 0.85034 \\
\hline 10 & 0.85012 & 0.85008 & 0.85006 & 0.85002 & 0.85032 & 0.85032 \\
\hline 15 & 0.85009 & 0.85009 & 0.85006 & 0.85002 & 0.85030 & 0.85030 \\
\hline 20 & 0.85001 & 0.85064 & 0.85010 & 0.85004 & 0.85029 & 0.85028 \\
\hline 25 & 0.85013 & 0.85016 & 0.85014 & 0.85007 & 0.85035 & 0.85032 \\
\hline 30 & 0.85017 & 0.85020 & 0.85017 & 0.85010 & 0.85034 & 0.85033 \\
\hline 35 & 0.85018 & 0.85027 & 0.85031 & 0.85014 & 0.85036 & 0.85031 \\
\hline 各電池平均值 & 0.8502 & 0.8502 & 0.8501 & 0.8501 & 0.8503 & 0.8503 \\
\hline
\end{tabular}

此の平均值を用ひ（3）式を出したるこ同樣の力法により次の値を得。

$$
\mathrm{H}_{2} \mathrm{O}=\mathrm{H}_{2} \mathrm{O}\left(33 \% \mathrm{NaOH} \text { 中の); } \Delta \mathrm{F}_{298}=-609 \mathrm{cal}\right. \text {. }
$$

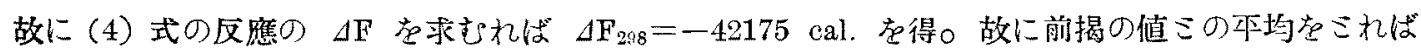

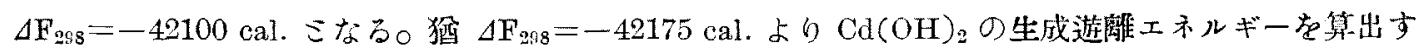
れば

$$
\mathrm{Cd}(\mathrm{s})+\mathrm{H}_{2}(1 \mathrm{Atm} .)+\mathrm{O}_{2}(1 \mathrm{Atm} .)=\mathrm{Cd}(\mathrm{OH})(\mathrm{s}) ; \Delta \mathrm{F}_{2 ! 8}=-112543 \mathrm{cal} .
$$

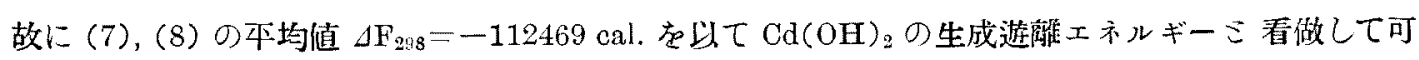
なるべし。

\section{[3.] 水酸化カドミゥムの水恙による還元の遊離エネルギー}

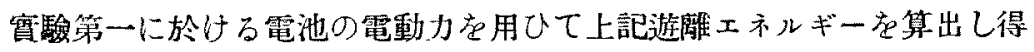

$\mathrm{Cd} \mid \mathrm{Cd}(\mathrm{OH})_{2} \mathrm{~N} \mathrm{NaOH} ; \mathrm{E}_{298}=0.7968$ (前出)

Lewis Randall ${ }^{12}$ によれば

$$
\mathrm{H}_{2} \mid \mathrm{OH}^{-} ; \mathrm{E}_{2 \Omega 8}^{\circ}=0.8280
$$

今 $1 \mathrm{~N} \mathrm{NaOH} の$ Activity coefficient $r=0.68^{2)} \Xi し て \mathrm{E}=\mathrm{E}^{\circ}+\frac{\mathrm{RT}}{\mathrm{nF}} \ln \mathrm{a}^{-}$に入るれば

$$
\mathrm{H}_{2} \mid \mathrm{N} \mathrm{NaOH} ; \mathbf{E}_{248}=0.8181
$$

故に

$$
\mathrm{H}_{2}\left|\mathrm{~N} \mathrm{NaOH} \mathrm{Cd}(\mathrm{OH})_{2}\right| \mathrm{Cd} ; \mathrm{E}_{298}=0.0213
$$

從つて

$$
\mathrm{Cd}(\mathrm{OH})_{2}+\mathrm{H}_{2}=\mathrm{Cd}+2 \mathrm{H}_{2} \mathrm{O}\left(\mathrm{N} \mathrm{NaOH} \text { 中の) } ; \Delta \mathrm{F}_{2: 8}=-983 \mathrm{cal}\right. \text {. }
$$

それミ(3) 式の二倍より

$$
\mathrm{Cd}(\mathrm{OH})_{2}+\mathrm{H}_{2}=\mathrm{Cd}+2 \mathrm{H}_{2} \mathrm{O} \quad ; \Delta \mathrm{F}_{298}=-949 \mathrm{cal} .
$$

1) Lewis Randall: Thermodynamics, p. 408.

2) J. Am. Chem. Soc., 47, 680 (1925). 
本研究の結果を總括すれば次の如し。

(1) $\mathrm{Cd}(\mathrm{OH})_{2} の$ Activity 積及び溶解度を決定せり、其の値各ヶ $1.17 \times 10^{-14}$ 及び $1.4 \times 10^{-5}$ モル/立なり。

(2) $\mathrm{Cd}(\mathrm{OH})_{2} の$ 溶解度の近似值を得万目的には電塺滴定法にて充分なるここを知りたり。

（3）水酸化カドミウムの生成遊雄エネルギーを決定せり、即ち

$$
\mathrm{Cd}(\mathrm{s})+\mathrm{H}_{2}(1 \mathrm{Atm} .)+\mathrm{O}_{2}(1 \mathrm{Atm} .)=\mathrm{Cd}(\mathrm{OH})_{2}(\mathrm{~s}) ; \Delta \mathrm{F}_{298}=-112469 \mathrm{cal} .
$$

(4) $\mathrm{Cd}(\mathrm{s})+\mathrm{HgO}(\mathrm{s})+\mathrm{H}_{2} \mathrm{O}(\mathrm{l})=\mathrm{Cd}(\mathrm{OH})_{2}(\mathrm{~s})+\mathrm{Hg}(\mathrm{l}) ; \Delta \mathrm{F}_{298}=-42100 \mathrm{cal}$.

(5) $\mathrm{Cd}(\mathrm{OH})_{2}(\mathrm{~s})+\mathrm{H}_{2}(1 \mathrm{Atm})=.\mathrm{Cd}(\mathrm{s})+2 \mathrm{H}_{2} \mathrm{O}(\mathrm{l}) ; \Delta \mathrm{F}_{9 \mathrm{~g} 8}=-949 \mathrm{cal}$.

(昭和二年三月 仙臺、東北帝國大學理學部化學教室)

\title{
青化水素水溶液の蒸氣壓測定 $\left(18.0^{\circ} \mathrm{C}\right)$
}

\author{
（昭和二年三月一日受領 昭和二年六月二十五日印刷）
}

白土萬次郎

\section{I. 緒}

言

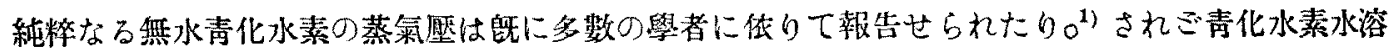

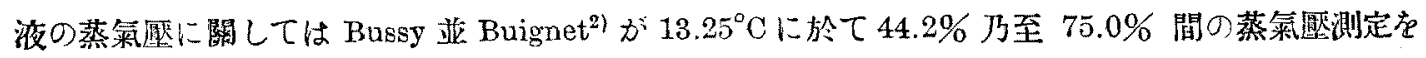
賽施したる一文獻を發見したるのみ、依りて著者は $18.0^{\circ} \mathrm{O}$ に於ける青化水素水溶液の蒸氧歷を测定 したり。

\section{II. 青化水素の製法}

含水亚に無水青化水素の製法に種々おり尚即ち青化吅里ミ硫酸ミより又は7ェ口青化加里ミ硫酸ミ より又は青化加里ミ酒石酸こより㱔するを得。Gattermann ${ }^{4}$ は既に之れが適當なる製造装置を報告 せり、著者の探用せる裝置は之を適宜改良したるものなり。

著者は成可的純粹なる物質より含水並に篦水青化水素を慗する方法を呼究せり。著者は Clarkに 從ひて純青化加里ミ酒石酸より含水青化水素を製せしも反應緩慢にして 5 時間繼續蒸溜後其得率 $80 \%$ にして溜出液中の青化水素の濃度は凡 $14 \%$ に過ぎざりき。次に著者は黃血監ミ燐酸庄使用す 万方法を試みたり、著者の方法に據れば 2 時間繼績蒸溜後其得卒 $85 \%$ にして青化水素の漫度は $55-60 \%$ なりき。

1) Bussy und Buignet. Ann. Chim. [4] 3, 245 (186t); Gautier, Ann. Chim. [4] 17, 103 (1869); Isambert,

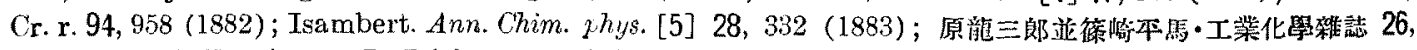
884 (1923); G. Bredig und L. Teichmann. Z. Elektrochem. 31, 450 (1925); J. H. Perry and Frank Porter. J. Am. Chem. Soc. 48, 299 (1926).

2) Bussy und Buignet, 前出。

3) Gattermann. Am. 357, 318 (1907); Wade \& Panting. Soc. 73, 255 (1898); E. Schmidt. Ber. 55, 97 (1922); 原並箫崄. 工化、26,884 (1923); G. Bredig u. L. Teichmann. Z. Elektrochem. 31, 449 (1925).

4) Gattermann, 前出。 